\title{
Cultural Energy Expended in Range Meat and
}

\section{Fiber Production}

\section{WAYNE COOK}

Highlight: Range livestock production requires more cultural energy than commonly believed. However the cultural energy expended for range meat and fiber is considerably less than that required in confined fattening procedures. Complementing rangelands with dryland forages offers great promise in decreasing the cost of fossil fuel to produce a pound of red meat for human consumption, compared to feedlot fattening.

Oil and gas in the United States are finite resources and predictions are that there are only a 50-year supply of gas and a 75-year supply of oil at the present rate of usage. It is true that we have several hundred years' supply of coal and a rather vast energy reserve in oil shale and nuclear material, but they too are finite and expensive to develop as substitutes for gas and oil. Therefore the public is becoming conscious of the use of fossil fuels, whether it be for pleasure or for the production of food. In the latter case, a close correlation will develop between the cost of a product and the expenditure of cultural energy to produce it.

It is of interest to evaluate the cultural energy expended in the production of food and particularly meat because meat comes from the second feeding level in the food chain and therefore requires more subsidized energy in the conversion of solar energy than do plant foods.

\section{Measures of Cultural Energy}

Cultural or subsidized energy is the energy other than solar energy needed to produce food and fiber. Cultural energy includes labor, manufacture of machinery, transportation, tillage, production of fertilizers and herbicides, processing material, and finally marketing the product (Cook et al., 1976).

Calculations of cultural energy input for labor were 2,500 kcal per hour, for depreciation and maintenance of large machinery were $45,000 \mathrm{kcal}$ per hour of operation, gasoline per gallon contains $31,056 \mathrm{kcal}$, transportation requires $4 \mathrm{kcal}$ per pound per mile (Cook et al., 1976). Electricity was calculated to be about $860 \mathrm{kcal}$ per kilowatt hour (Table 1). Electricity was calculated as being only $40 \%$ efficient because it requires 2.5 more BTU's of coal to produce the equivalent kilowatt hours of electricity. This is a result of the loss of

Author is head, Department of Range Science, Colorado State University, Fort Collins, 80523.

Manuscript received January 15, 1976. energy in heat when steam is used to produce power to turn the turbines. This does not include the cultural energy required to mine the coal and transport it to the generating sites or the loss in transmission lines. In the Central Plains area it was determined that about $80 \%$ of the electricity comes from steam generators and $20 \%$ from hydroelectric sources. Sorghum produced on summer-fallowed ground for grazing required $495.7 \mathrm{Mcal}$ per acre and feeds used in supplements and rations varied from 350 to $500 \mathrm{kcal}$ per pound (Cook et al., 1976).

\section{Range Sheep Production in the Intermountain Great Basin}

The sheep ranches included in the study were typical of many operations in Utah, Nevada, and southern Idaho, where sheep graze desert ranges during the wintcr from about November 1 until about A pril 1, after which they are trailed onto foothill range where they lamb on crested wheatgrass and/or native grass-sagebrush types. About the middle of June they are moved into mountain brush types and subsequently in to higher mountain zones.

In this study all lambs were black-face crosses. All cultural energy expenditures were made on the basis of a 1,800 mature ewe herd with 200 replacements, 36 bucks, and 3 to 4 horses. From these operations about $70 \%$ of the lambs were sold as grass-fat choice lambs weighing about $90 \mathrm{lb}$ with a 50.9 dressing percentage. The dressed carcass was $16.2 \%$ protein and $23.4 \%$ fat. The remaining $30 \%$ of the lambs weighed $75 \mathrm{lb}$ and sold as feeders which dressed $47.5 \%$ with $17.1 \%$ protein and $18.8 \%$ fat.

All carcass protein was considered to possess $5.7 \mathrm{kcal}$ of gross energy per gram and all fat was calculated as having 9.4 kcal per gram.

The sheep, while on the desert ranges, were supplemented from December 15 until March 15 at the rate of one-half pound per head every other day. The supplement consisted of $45 \%$ alfalfa, $25 \%$ barley, and $30 \%$ soybean meal. The cultural energy in the alfalfa, barley, and soybean meal was $272 \mathrm{kcal}$, $411 \mathrm{kcal}$, and $658 \mathrm{kcal}$ per pound of material respectively. The mixture was fed in pelleted form and was purchased at a feed mill and transported to the desert range about 48 miles away.

It was calculated that $2.24 \mathrm{kcal}$ of cultural energy was expended for each kilocalorie in dressed carcass meat and 1.54 Mcal of cultural energy was used for each pound of live weight of lamb produced (Table 2). 
Table 1. Average cultural energy expended for various range sheep and cattle operations compared to typical feediot operations on the eastern slope of the Rocky Mountains.

\begin{tabular}{|c|c|c|c|c|c|c|c|c|c|c|c|c|}
\hline & \multicolumn{4}{|c|}{ Intermountain Great Basin } & \multicolumn{6}{|c|}{ Central Great Plitins } & \multirow{2}{*}{\multicolumn{2}{|c|}{$\frac{\text { Central Plains }}{15,000 \text { feedlot operation }}$}} \\
\hline & \multicolumn{2}{|c|}{$\begin{array}{l}\text { Range sheep' } \\
2.000 \text { female herd }\end{array}$} & \multicolumn{2}{|c|}{$\begin{array}{l}\text { Range cows' } \\
250 \text { temale herd }\end{array}$} & \multicolumn{2}{|c|}{$\begin{array}{l}\text { Range-sorghum' } \\
250 \text { cow operation }\end{array}$} & \multicolumn{2}{|c|}{$\begin{array}{l}\text { Range cows' } \\
250 \text { female herd }\end{array}$} & \multicolumn{2}{|c|}{$\begin{array}{l}\text { Range-sorghum } \\
400 \text { steer operation }\end{array}$} & & \\
\hline & Quantity & Mcal & Quant ity & Mcil & Quantity & Meal & Ouantity & Mal & Ouantity & Mall & Quantity & Mal \\
\hline Labor (hour) & 6,080 & 15,200 & 3.170 & 7.925 & 2.737 & 6.842 & 2.737 & 6.842 & 3,780 & 9.450 & 16.320 & 40.800 \\
\hline Machinery (hour) & 1.500 & 67.500 & 1.200 & 54,000 & 1.744 & 78.480 & 1.744 & 78.480 & 1.900 & 85,500 & 16.320 & 734.400 \\
\hline Gasoline (gal) & 5.166 & 160.435 & 3.500 & 108.696 & 3.959 & 122.951 & 3,959 & 122.951 & 4.500 & 139.752 & 29.070 & 902,798 \\
\hline Transportation (miles $\times$ lb) & 2.305 .0001 & 9200 & $2,380,000$ & 9.520 & 27.257 & 109 & 27.257 & 109 & 194.444 & 778 & $2,253 \times 10^{6}$ & $9,012,000$ \\
\hline Llectricity (KW hour) & & & & - & - & - & & -- & & - & 122.559 & 105,400 \\
\hline leed (lb) & 45.000 & 19.350 & 45.000 & 22.500 & 67.500 & 23,490 & 67.500 & 23.490 & 180.000 & 62.640 & 133.875 .000 & $59,440,500$ \\
\hline Sorghum pasture (acre) & & & & - & 109 & 54,035 & & & 171 & 84.769 & - & - \\
\hline Total cult ural energy (M cai) & & 271,705 & & 202.641 & & 285.907 & & 231.872 & & 382.889 & & 70.235 .898 \\
\hline
\end{tabular}

Total cultural energy (Meii)

271,705

There were $130,410 \mathrm{lb}$ of choice lamb, which sold for $44 \phi$ a pound, totaling $\$ 57,380.00 ; 46,575 \mathrm{lb}$ of feeder lamb, which sold for $42 \notin$ for a total gross income of $\$ 19,561.00$; and $20,000 \mathrm{lb}$ of wool, which brought $72 \notin$ or a total of $\$ 14,400.00$. Thus $84 \%$ of the sales came from lambs and $16 \%$ from wool. Therefore $16 \%$ of the total Mcal of cultural energy $(16 \times 271,705 \mathrm{Mcal})$ or $43,473 \mathrm{Mcal}$ can be assessed to wool production. The Mcal of cultural energy for shearing was calculated as follows: 184 man hours amounting to $460 \mathrm{Mcal}$, machinery totaling $4,259 \mathrm{Mcal}$, the transportation of wool to market amounted to $14,400 \mathrm{Mcal}$, and finally the scouring using 3,600 Mcal. The total expenditure of cultural energy for shearing, handling, and processing wool was 22,719 Mcal. Thus the addition of $43,473 \mathrm{Mcal}$ of cultural energy resulting from $16 \%$ of the general operational energy costs and the 22,719 Mcal expended in actual shearing, transportation, and scouring of the wool would be $66,192 \mathrm{Mcal}$ for $8,000 \mathrm{lb}$ of clean wool or $8.27 \mathrm{Mcal} / \mathrm{lb}$ of scoured wool.

In a recent report by the National Cotton Council of America (Gatewood, 1973) it was estimated that cultural energy consumed in a pound of cotton lint was $3.22 \mathrm{Mcal}$ and the cultural energy cost for noncellulosic and cellulosic synthetic fibers per pound was 15.17 and 20.38 Mcal, respectively. The noncellulosic fiber included polyester, nylon, and acrylic material, which are petro-chemicals or derived from petroleum or natural gas.

Cotton has a significant advantage in the amount of cultural energy required for fiber production since the cotton plant not only produces fiber but also produces cotton seed oil and cotton seed meal. Wool, like cotton, is a by-product or a dual product of the sheep industry and requires considerably less cultural energy than synthetic fibers.

\section{Range Cattle Production in the Intermountain Great Basin}

The 250-head cattle ranches that were analyzed in the
Intermountain Great Basin area operate somewhat similarly to sheep ranches of the region. Typical cow-calf operations throughout Utah, Nevada, and southern Idaho, like sheep operations, run on desert ranges during the winter from about November 1 to April 1 and are grazed on crested wheatgrass and/or native range during calving and until about the third week in June, when they move to mountain ranges until about October 1.

The supplement for cattle consisted of 30\% alfalfa, 20\% barley, and $50 \%$ soybean meal. This was fed to cattle in pelleted form for 90 days at the rate of $2 \mathrm{lb} /$ day per animal. The supplement was hauled about 48 miles from the feed mill to the range where it was fed.

The percent calf crop was 93\% and all calves were Hereford $X$ Angus crosses, which sold at weaning time as good grade grass-fat calves weighing $405 \mathrm{lb}$. They dressed at $57.9 \%$ with the carcass containing $11.2 \%$ fat and $16.6 \%$ protein that totaled $212,437 \mathrm{kcal}$.

The expenditure of cultural energy per pound of weaning weight was $2.15 \mathrm{Mcal}$; the ratio of cultural energy used per increment of food energy produced in the dressed carcass was 4.09 (Table 2).

\section{Range Cattle Production in the Central Plains}

In the central plains states of Nebraska, Kansas, Oklahoma, northern New Mexico, and eastern Colorado, a typical cow-calf operation remains on the range all or most of the year with only a few pounds of supplement fed during the winter months. Calves are dropped in mid-April generally. Cows, during calving, continuc to reccive a supplement until green growth starts on the ranges, which occurs during early May. The cow-calf unit is grazed on rangelands until about the middle of October, when the calves are weaned and sold.

In some cases forage sorghums are planted for summer grazing from about July 15 until weaning time. This is referred

Table 2. Average output of meat and energy compared to cultural energy input from various range sheep and cattle ranches and typical feedlot operations in the western range area.

\begin{tabular}{|c|c|c|c|c|c|c|}
\hline & \multicolumn{2}{|c|}{ Intermountain Great Basin } & \multicolumn{3}{|c|}{ Central Great Plains } & \multirow{2}{*}{$\begin{array}{c}\begin{array}{c}\text { Central } \\
\text { Plains }\end{array} \\
\begin{array}{c}15,000 \\
\text { feedlot } \\
\text { operation }\end{array}\end{array}$} \\
\hline & $\begin{array}{l}\text { Range sheep } \\
2,000 \text { female } \\
\text { herd }\end{array}$ & $\begin{array}{l}\text { Range cows } \\
250 \text { female } \\
\text { herd }\end{array}$ & $\begin{array}{c}\text { Range-sorghum } \\
250 \text { cow } \\
\text { operation }\end{array}$ & $\begin{array}{l}\text { Range cows } \\
250 \text { female } \\
\text { herd }\end{array}$ & $\begin{array}{c}\text { Range-sorghum } \\
400 \text { steer } \\
\text { operation }\end{array}$ & \\
\hline Market weight or gain (lb) & $85.5^{1}$ & $405^{2}$ & $445^{3}$ & 414 & 396 & 586 \\
\hline Calf or lamb crop $(\%)$ & 103.5 & 93 & 93 & 92 & $98^{4}$ & $99^{5}$ \\
\hline Total energy in carcass (Mcal) & 121,382 & 49,498 & 54,423 & 50,578 & 138,138 & $13,186,800$ \\
\hline No. marketed & 2,070 & 233 & 233 & 230 & 392 & 14,850 \\
\hline Live weight marketed (lb) & 176,985 & 94,365 & 103,685 & 95,220 & 155,232 & $8,702,100$ \\
\hline Cultural energy/food energy & 2.24 & 4.09 & 5.25 & 4.58 & 2.77 & 5.33 \\
\hline Mcal cultural energy/lb of live weight & 1.54 & 2.15 & 2.76 & 2.44 & 2.47 & 8.07 \\
\hline
\end{tabular}

$170 \%$ sold as choice fat lambs at $90 \mathrm{lb}$ and $30 \%$ sold as feed lambs at $75 \mathrm{lb}$.

${ }^{2}$ All sold as good grass fat calves.

${ }^{3} 70 \%$ sold as choice grass fat calves.

4 Percent death loss was $2 \%$, therefore $98 \%$ was marketed, all sold as good grade grass fat steers weighing $810 \mathrm{lb}$.

${ }^{5}$ Percent death loss was $1 \%$, therefore $99 \%$ was marketed, $70 \%$ sold as choice and $30 \%$ as good grade fed beef weighing an average of $1,000 \mathrm{lb}$. 
to as a range-sorghum operation for producing grass-fat weaner calves that sell as choice grade feeder calves and weigh about $445 \mathrm{lb}$. For practical purposes the dressing percentage and the percent fat and protein in the carcass were considered the same as for the calves produced to choice grass-fat feeders in the Intermountain Great Basin area discussed previously.

The ratio of cultural energy used to produce an increment of food energy in meat was 5.25 for the cow-calf units that grazed range in conjunction with forage sorghum pastures for fat weaner calf production and 4.58 for the typical cow-calf range operation in the Central Plains region. The rangesorghum grazing system expended $2.76 \mathrm{Mcal}$ of cultural energy per pound of weaner calf compared to $2.44 \mathrm{Mcal} / \mathrm{lb}$ of calf gain for the conventional range cow-calf operation (Table 2). The development of the forage sorghum pastures increased the expenditure of cultural energy because of the tillage and plantings of these pastures.

In all cases winter supplement was fed to the breeding cow herd from about the middle of December until about May 1 at the rate of $2 \mathrm{lb}$ per head per day. The supplement used in the calculations consisted of $60 \%$ alfalfa, $20 \%$ soybean meal, and $20 \%$ milo, which averaged $348 \mathrm{kcal}$ of cultural energy per pound of pelleted feed mixture.

The weaning weight from the range-sorghum grazing system produced calves weighing $445 \mathrm{lb}$ at weaning about October 15; the conventional range cow-calf operation produced weaner calves weighing $414 \mathrm{lb}$. All of the weaner calves in the range-sorghum feeding system were graded as choice grass fat feeder calves, whereas only $70 \%$ of the calves produced solely from range forage sold as choice.

\section{Steer Operations in the Central Plains}

Many ranchers of the western range region have shifted from a cow-calf operation to an enterprise of growing steers. These animals are purchased as weaner calves and sold in the spring and summer as feeders. However, more and more operators are fattening such steers on mountain summer ranges or summer-fallowed forage sorghum pastures in the Central Great Plains area. If properly managed, the steers can be sold from these systems weighing over $800 \mathrm{lb}$ at 17 to 18 months of age and grading as good for block meat. Such meat is now marketed by many chain stores under various trade names.

Experiments in Colorado showed that these steers gained from $414 \mathrm{lb}$ as weaners to $810 \mathrm{lb}$ when sold from the forage sorghum pastures in late summer. These 800 -1b steers dress at $58.0 \%$ with $20.1 \%$ fat and $14.4 \%$ protein in the carcass. Again it was calculated that fat contained $9.4 \mathrm{kcal} / \mathrm{g}$ and protein contained $5.7 \mathrm{kcal} / \mathrm{g}$.

In this study range steers were fed $3 \mathrm{lb}$ of supplement per day from December 15 to May 15. The pelleted supplement contained $60 \%$ alfalfa, $20 \%$ soybean meal, and $20 \%$ barley, which had a cultural energy cost of $348 \mathrm{kcal} / \mathrm{lb}$.

From the 400-steer operation analyzed it was calculated that $2.77 \mathrm{kcal}$ of cultural energy were required for each kilocalorie of dressed meat produced and 2.47 Mcal of cultural energy for each pound of steer gain (Table 2).

\section{Feedlot Operations}

A typical 15,000 feedlot capacity operation in the plains area near Denver, Colorado, was analyzed in this study. The animals fed consisted of $62 \%$ steers and $38 \%$ heifers. They were fed for 255 days, starting with an average weight of 414 $\mathrm{lb}$ and finishing at $1,000 \mathrm{lb}$. Thus the overall daily gain was 2.3 $\mathrm{lb} / \mathrm{day}$.

The ration the first 122 days was about $60 \%$ roughage, consisting of corn silage, chopped alfalfa, and beet pulp along with $40 \%$ dry rolled corn and soybean meal. During the next 133 days the ration was about $65 \%$ concentrates, consisting of dry rolled corn and soybean meal, along with $30 \%$ corn silage and $5 \%$ molasses. All silage was raised near the feeding operation and $40 \%$ of the corn was raised on the owned land. The remainder of the feed was hauled onto the farm feedlot from feed mills 15 miles away.

The avcrage cultural energy for the ration during the first 122 days was $389 \mathrm{kcal}$ of cultural energy per pound of feed and for the ration fed during the next 133 days was $495 \mathrm{kcal}$ of cultural energy per pound of feed. The average for the entire 255-day feeding period was $444 \mathrm{kcal} / \mathrm{lb}$ of feed. The average daily intake per animal over the 255-day feeding period was $35 \mathrm{lb}$. During the early feeding period, daily consumption was $22 \mathrm{lb}$ but was as high as $39 \mathrm{lb}$ during the latter part of the feeding period.

The heifers dressed at $60.5 \%$ and the steers dressed at $62.5 \%$, which was a weighted average of $61.7 \%$ for the 14,850 head marketed. Approximately $79 \%$ graded choice and $21 \%$ graded good.

It was calculated that an average $1,000-\mathrm{lb}$ animal dressed at $62 \%$ with a $4 \%$ shrink and the carcass containing $35 \%$ fat and $11.8 \%$ protein, which yielded $1,108 \mathrm{Mcal}$ of energy per dressed carcass. The dressed carcass of the 414-1b weaner range calf had $220 \mathrm{Mcal}$; therefore the 255 -day feeding period produced $888 \mathrm{Mcal}$ per carcass from the 586 pounds gained per animal. With a $1 \%$ death loss the total Mcal from the dressed carcass was $13,186,800$ for 14,850 animals marketed (Table 2).

Under a fattening program under confinement feeding, 5.33 $\mathrm{kcal}$ of cultural energy were required to produce a kilocalorie of dressed carcass meat. Each pound gained required $8.07 \mathrm{Mcal}$ of cultural encrgy (Table 2). These figures were considerably higher than those for a combination of range and foragesorghum pastures, which were 2.77 and $2.47 \mathrm{Mcal}$ of cultural energy for a Mcal of meat and per pound of gain, respectively.

\section{Complete Systems from Conception to Marketing}

The total expenditure of cultural energy including the cow-calf and ewe-lamb operations until animals reached various marketable weights and ages is shown in Table 3. Sheep are considerably more efficient than cattle. This is a result of multiple births, faster growth rate, and ability to fatten to choice grade on range forage without grain. A ewe produces almost $62 \%$ of her weight as weaner lamb and a cow produces only about $45 \%$ of her weight as weaner calf in the same period. The cow-calf unit can be most competitive with the ewe-lamb unit in the production of red meat from forage by finishing steer calves to good grade on sorghum pastures.

The expenditure of cultural energy to produce a choice grade beef from conception to a $1,000-\mathrm{lb}$ animal was of course the most inefficient in the use of cultural energy because of the use of harvested roughage and grain.

In the present study it required $5.74 \mathrm{Mcal}$ of cultural energy to produce $1 \mathrm{lb}$ of fattened choice grade beef. Comparable figures by Lockeretz (1975) showed that 4.54 Mcal per pound of beef from birth to feedlot fattening was required. In the same study for use of irrigated pastures along with feedlot finishing in Oklahoma, $11.6 \mathrm{Mcal}$ of cultural energy were required to produce a pound of finished beef. 
Table 3. Average production of live weight along with expenditure of cultural energy per increment of energy produced and per pound of live weight gain for various systems of producing marketable lamb and beef on an individual basis at the source of production.

\begin{tabular}{|c|c|c|c|c|}
\hline & $\begin{array}{c}\text { Lamb }^{1} \\
\text { production }\end{array}$ & $\begin{array}{c}\text { Weaner } \\
\text { calf }^{2} \\
\text { production }\end{array}$ & $\begin{array}{l}\text { Steer }{ }^{3} \\
\text { production } \\
\text { on forage }\end{array}$ & $\begin{array}{l}\text { Feedlot } \\
\text { fattening }\end{array}$ \\
\hline $\begin{array}{l}\text { Weight produced } \\
\text { (lb) }\end{array}$ & 85.5 & 414 & 810 & 1000 \\
\hline $\begin{array}{l}\text { Energy in dressed } \\
\text { carcass (Mcal) }\end{array}$ & 58.6 & 220 & 527 & 1108 \\
\hline $\begin{array}{l}\text { Cultural energy } \\
\text { expended (Mcal) }\end{array}$ & 131.3 & 1010 & 1987 & 5740 \\
\hline $\begin{array}{l}\text { Cultural energy } \\
\text { in/energy out }\end{array}$ & 2.24 & 4.58 & 3.47 & 5.18 \\
\hline $\begin{array}{l}\text { Cultural energy } \\
\text { in/lb of live } \\
\text { weight (M cal) }\end{array}$ & 1.54 & 2.44 & 2.45 & 5.74 \\
\hline
\end{tabular}

${ }^{1}$ Ewes were white-face crosses weighing an average of $139 \mathrm{lb}$.

${ }^{2}$ Cows were good grade Hereford cows weighing an average of $914 \mathrm{lb}$.

${ }^{3}$ Calculated for an animal including the cow-calf operation until finished either on forage or in the feedlot.

\section{Summary}

The sheep industry has the advantage of producing choice grade meat directly off the range at a cost of only $2.24 \mathrm{kcal}$ of cultural energy per kilocalorie of dressed carcass compared to cattle which required approximately $4.5 \mathrm{kcal}$ per kilocalorie of dressed meat for weaner calves.

By using range along with forage-sorghum pastures, a good grade animal that was raised from a calf to a steer weighing $810 \mathrm{lb}$ can be produced for an expenditure of about $3.5 \mathrm{kcal}$ of cultural energy for each kilocalorie of dressed carcass and a choice weaner calf weighing $445 \mathrm{lb}$ can be produced on range and forage sorghums for a cost of $5.25 \mathrm{kcal}$ of cultural energy per kilocalorie of dressed meat. By intensive management of a cow-calf operation in the Intermountain Great Basin area, where crested wheatgrass is used for early spring grazing and good mountain range is used from June 15 to September 15, a kilocalorie of dressed choice weaner-calf meat can be produced at a cost of $4.09 \mathrm{kcal}$ of cultural energy.

Thus it appears that the lowest expenditure of cultural energy per kilocalorie of table meat is from lamb and meat from steers produced to good grade largely from range and forage-sorghum pastures.

The expenditure of cultural energy per pound of live weight gain of marketable animals was only $1.54 \mathrm{kcal} / \mathrm{lb}$ of gain for a ewe-lamb operation and $2.15 \mathrm{kcal} / \mathrm{lb}$ of gain for a cow-calf operation in the Intermountain Great Basin area, compared to 2.76 and $2.44 \mathrm{kcal} / \mathrm{lb}$ of gain in the Central Great Plains where forage sorghums are used for summer grazing and the conventional range operation for weaner calf production, respectively.

The steer operation that starts from birth and makes use of range and forage sorghums to a weight of $810 \mathrm{lb}$ required 2.45 $\mathrm{kcal}$ of cultural energy per pound of body gain. Feedlot operations that start from birth and feed the weaner calf for 255 days to a final weight of $1,000 \mathrm{lb}$ required $5.74 \mathrm{kcal}$ of cultural energy per pound of live weight gain.

The relative cost of cultural energy per pound of body gain under the various livestock operations follows the same ranking as the kilocalories of cultural energy expended per kilocalorie of dressed meat. A ewe-lamb operation is most efficient, with a steer operation next. These are followed by the conventional range cow-calf operation, the range-sorghum pasture grazing system, and finally the feedlot fattening procedure.

\section{Literature Cited}

Cook, C. Wayne, A. H. Denham, E. T. Bartlett, and R. Dennis Child. 1976. Efficiency of converting nutrients and cultural energy in various feeding and grazing systems. J. Range Manage. 29:186-191.

Gatewood, L. B., Jr. 1973. The energy crisis: can cotton help meet it? Nat. Cotton Counc. Amer. Jan. Rep.

Lockertz, William. 1975. Agricultural resources consumed in beef production. Center for Biol. of Natur. Syst., Washington Univ., St. Louis, Mo. 